\title{
For Whom Hesperus Shines: An Astronomical Allusion in Roman Epithalamic Poetry*
}

\author{
FABIO GUIDETTI
}

\author{
ABSTRACT
}

This paper reconstructs the history and meaning of a hitherto unexplained astronomical allusion recurring several times in Roman epithalamic poetry: the association of the evening star with Mount Oeta. By examining the iterations of this motif in surviving Latin literature (especially Catullus 62, Vergil's Eclogue 8 and the pseudo-Vergilian Ciris), I propose to explain the original meaning of this association as a mythological reference to the wedding of Peleus and Thetis, offering a reconstruction of the Hellenistic epithalamic context where it was probably invented, and an interpretation of its function in each of the poems under consideration. The results of this analysis shed new light on some of the most well-known texts of Latin literature, allowing us to understand how this allusion was used to explore the relations between the genres of epithalamic poetry, bucolic and epyllion.

Keywords: astronomy; Catullus; epithalamic poetry; evening star; Hellenistic poetry; Vergil

\section{INTRODUCTION}

Latin poetry is particularly rich in astronomical references, so that, as Quintilian warns (Inst. I.4.4), readers ignorant of the sky might miss important aspects of a poetic text. This article aims to decode one such reference: the association of the planet Venus, in its appearance as the evening star, with Oeta, a mountain located between Thessaly and Aetolia. This association, attested among others in Catullus 62, Vergil's Eclogue 8 and the pseudo-Vergilian Ciris, has never been satisfactorily explained. Some have taken it as evidence that the events described in these poems are taking place near that mountain, while others have interpreted it as a purely literary reference unrelated to the immediate context. ${ }^{\text {I }}$ The latter view was put forward most explicitly by Eduard Fraenkel, who stated that 'Oetaeus had become to the Roman poets, presumably after some Hellenistic model, a common epithet of Hesperus, to be used at random'. ${ }^{2}$ The suggestion that the

\footnotetext{
* This research was financed with the support of the European Union Framework Programme for Research and Innovation 'Horizon 2020' (H2020-MSCA-IF-20I7/Grant Agreement no. 792387) and the 2018-2022 'Department of Excellence' project I tempi delle strutture. Resilienze, accelerazioni e percezioni del cambiamento (nello spazio euro-mediterraneo) - Linea di ricerca Mondo Antico of the Dipartimento di Civiltà e forme del sapere, University of Pisa. I am indebted to Gavin Kelly, Adalberto Magnavacca, Luca Ruggeri, Giulio Vannini and the anonymous reviewers for many suggestions and improvements.

1 A summary of the debate in Agnesini 2007: I66-7, 373-6; Fo 2018: 734-5, 74I, 743.

2 Fraenkel I955: 3 .
}

JRS II 2 (2022), pp. 39-56. (C) The Author(s), 2022.

Published by Cambridge University Press on behalf of The Society for the Promotion of Roman Studies. This is an Open Access article, distributed under the terms of the Creative Commons Attribution licence (bttps:/l creativecommons.org/licenses/by/4.o/), which permits unrestricted re-use, distribution, and reproduction in any medium, provided the original work is properly cited.

doi:IO.IOI $7 /$ SoO 543582 I000903 
association refers back to some Greek model is certainly correct: the way the Latin poets introduce it, without providing any explanation, shows that they are building on an established commonplace. But it takes a good deal of confidence in one's own exegetical skills to assume that, if one is not able to explain an author's word choice, then this word must be 'used at random'. The connection of Hesperus to Oeta calls for better clarification. Unless some fortunate papyrological discovery comes to our aid, we will never be able to read the Greek text in which this connection was first made. However, this allusion is normally found in contexts related to weddings; it is therefore likely that the association was originally developed in the epithalamic genre. This may help us understand the meaning of both the original reference and the Latin authors' allusions.

The idea that the mention of Oeta should be read not as a geographical indication but as an erudite detail is not new. A remark along these lines is found already in Servius' note on Verg., Ecl. 8.30, who says that Oeta is 'a mountain of Thessaly from which stars are seen setting, in the same way as they are seen rising from Ida' - an opinion supported through the quotation of Aen. 2.80I. ${ }^{3}$ This is not, of course, an astronomical explanation: Servius just wants to point out that in Vergil stars are said to rise behind Ida and set behind Oeta. $\mathrm{He}$ is only interested in the consistency of his author's representation of space: if the association between Hesperus and Oeta entails a reference to an earlier model, Servius either does not notice or does not care. ${ }^{4}$

Some modern commentators also repeat information taken from the so-called Servius Danielis, the expanded version of the Servian commentaries. This compilation was probably based on a source that Servius also used, namely the lost commentary on Vergil by the fourth-century grammarian Aelius Donatus, and sometimes preserves valuable information not included in Servius' commentary. However, its compiler lived in the seventh or eighth century and had only a limited understanding of non-literary aspects of the Greek and Roman world. This is shown by his remarks on Ecl. 8.30. After summarising the most famous myth associated with Mount Oeta, that of Hercules' death and apotheosis, the commentator tries to explain why Hesperus is mentioned in an epithalamic context. He does so by turning both Hesperus and Hymenaeus into mythological figures and establishing an erotic relationship between them. This practice is not uncommon: several ancient authors exploited the personification of the planet Venus as a narrative device, turning it into a mythological character. ${ }^{5}$ However, all these instances refer to Heosphoros/Lucifer, i.e. the personification of the morning star, not to Hesperus. Even if the identity of the morning and evening stars was well known to Greeks and Romans, when it came to their personifications the distinction between them remained in place throughout antiquity. Therefore, it is doubtful that mentions of a personified Heosphoros can be relevant to explain references to the evening star. ${ }^{6}$ But the very fact that the compiler of the Servius Danielis chose to provide a

\footnotetext{
3 Serv., ad Ecl. 8.30: 'montem Thessaliae quo stellae uidentur occidere, sicut de Ida nasci, ut "iamque ingis summae surgebat Lucifer Ida"'. Here Thilo prints the text of Servius Danielis, not Servius, but the wording of Servius' text can be found in Thilo's apparatus criticus (Thilo I 887: 98).

4 This is a good example of Servius' attitudes and long-lasting influence, as perceptively described by Fowler 2019: 90: 'From a modern point of view [...] [Servius'] tendency is towards the removal of 'difficulties', rather than their incorporation into a more complex reading, but the same objection might be made to many modern commentaries. The range of interests is also similar to that of modern commentaries (unsurprisingly, since modern commentary has been shaped in part by the Servian model)'.

5 The sources are collected by Weizsäcker I884-I890 and Rehm I9 I 2: I 256.

6 Weizsäcker I884-I890: 2604. These mentions include Nonnus, Dion. 38.I37, where Heosphoros sings the wedding hymn at the marriage of Helios and Clymene, a passage sometimes cited as a parallel for the information given by the Servius Danielis (e.g. by Coleman I977: 235), but whose relevance in this context seems questionable. Heosphoros/Lucifer (not Hesperus) is also mentioned as the father of Ceyx, king of Trachis, a city at the base of Mount Oeta, by e.g. Ov., Met. II.27I and [Apollod.], Bibl. I.52. To my knowledge, the only author blurring the distinction between the personifications of the two aspects of the planet is Hyg., Fab. 65, who calls Ceyx 'Hesperi siue Luciferi ... filius'.
} 
mythological explanation of why Hesperus is mentioned in a wedding context is striking. The compiler seems unaware of the role of the evening star in the epithalamic tradition (where Hesperus is consistently referred to as a celestial body rather than a personification), thus showing limited knowledge of both ancient wedding rituals and Vergil's literary antecedents. The transformation of the evening star into a mythological figure (though unattested in extant ancient literature ${ }^{7}$ ) may well have featured, among other possible explanations, already in his late antique source. But it was probably the compiler who, after choosing this version over the others, turned this figure into a pagan god and explained the association with Oeta as referring to a cult of Hesperus existing on that mountain. This, however, is not confirmed by any other source or archaeological evidence; indeed, no cult of Hesperus is attested anywhere in the Greco-Roman world. ${ }^{8}$ Therefore, this explanation may be better understood as deriving from literary analogy: the compiler interpreted the association between Hesperus and Oeta in a similar way to other poetic references to mountains as gods' habitual seats (Jupiter and Olympus, Apollo and Parnassus, etc.). The reading of Vergil's line through this familiar trope inspired the idea that Oeta was the residence of a god named Hesperus and the seat of his cult.

All these arguments, I believe, especially the compiler's unawareness of the role of the evening star in an epithalamic context, make it difficult to argue that his explanation comes from a late antique source. Donatus wrote in the mid-fourth century, a time when pagan rituals (including weddings) were still performed, and surely would have been able to provide the correct explanation as to why Hesperus was mentioned in epithalamic poetry. The information found in the Servius Danielis is probably the product of the medieval compiler's imaginings. If this is true, then we should look for another reason behind the association of Hesperus with Mount Oeta. In the following pages I will explore the hypothesis that this is in fact an astronomical and geographical indication alluding to a specific epithalamic occasion.

\section{DECODING THE ALLUSION}

The easiest way to explain the association is to assume that, originally, it made sense as a topographical indication - in other words, that the Greek epithalamium alluded to by Catullus and Vergil narrated, or referred to, a wedding whose guests could see Hesperus shining above Oeta.

The evening star appears in the western sky after sunset. As is well known, the sun rises precisely in the astronomical east and sets precisely in the astronomical west only on the days of the equinoxes. In the northern hemisphere, in spring and summer the sun rises north of the astronomical east and sets north of the astronomical west; in autumn and winter it rises south of the astronomical east and sets south of the astronomical west. These differences increase with the distance from the Equator, so that the exact directions of sunrise and sunset on each day of the year vary depending on latitude. ${ }^{9}$ Since the evening star moves along the ecliptic like the sun, to assess its position with

\footnotetext{
7 Hesperus, Atlas' brother (Diod. Sic. 4.27.I-2), has no connection with the evening star; his name refers to his dwelling at the westernmost end of the known world.

8 In an attempt to substantiate the compiler's explanation, Rehm I9I 2: I255 mentions the depiction of a star on Locrian coinage (Head I 884: I, nos 2-6; 5, nos 35-36; I I, no. 2; I3, nos I-2) and a passage by Strabo saying that 'the western Locrians ... have the star Hesperus engraved on their public seal' (Str. 9.3.I). These references, however, are far from confirming the existence of a cult of Hesperus among the Locrians - let alone its location on Oeta, which was not part of Locrian territory.

9 As can be visualised through several online tools, for example http://suncalc.org (accessed 27/I I/202I).
} 
reference to a specific local horizon we need to know the latitude and period of the year at which the observation was made.

As I have said, the association of Hesperus with Oeta occurs in epithalamic contexts. In Greco-Roman antiquity marriages were normally celebrated in winter, when seasonal work could be paused without harming agricultural production: winter activities such as clearing, tillage, pruning could be put on hold with less detriment than reaping or harvesting. ${ }^{\text {IO }}$ It is easiest to assume that the epithalamic poet who first described the evening star appearing above Oeta imagined his ceremony as taking place in the normal wedding season. ${ }^{\text {II }}$ In winter, in this region of Greece $\left(c .39^{\circ} \mathrm{N}\right)$, the sun sets within an arc of the horizon extending for $c .3 \mathrm{I}^{\circ}$ from the astronomical west towards the south. The distance between the point where the sun sets and the astronomical west is greatest at the solstice and decreases day by day, reaching $0^{\circ}$ at the spring equinox. Based on the preferred wedding season in the ancient world, an angle between $25^{\circ}$ and $20^{\circ}$ (corresponding to the direction of sunset in late January/early February) seems a plausible guess. For the evening star to be seen above Oeta during this period, we must therefore posit an observer located north-east of the mountain, at an angle of $c .20^{\circ}-25^{\circ}$ with respect to the astronomical east. The place of observation must not be too close to the mountain, otherwise the latter will obstruct the horizon and the star will not be visible, but not too far from it, otherwise other landscape features may make the mountain difficult to see. Following these indications, we can identify a strip of land in south-eastern Thessaly, along the shore of the Malian Gulf and the Strait of Artemisium, as the ideal place of observation. From here, Oeta is located in the direction of sunset in early winter; the presence of the sea to the south-west ensures that no other landscape features obstruct the view. This is the area which the Iliad identifies as Phthia, the seat of Peleus' kingdom (Hom., Il. 2.68 I-684). Peleus' marriage to the goddess Thetis was a paramount event of the epic cycle, the triggering incident of the Trojan War and the premise for the birth of Achilles, the protagonist of the poem which shaped Greek identity more than any other literary work. ${ }^{\mathrm{I} 2}$ On this occasion, the wedding guests gathered in Phthia could have seen the evening star appearing above Oeta.

The sources are not consistent about the precise location of the wedding. Most of them, following the epic cycle, locate it on Mount Pelion: ${ }^{\mathrm{I} 3}$ a liminal place at the edge of the anthropised landscape, appropriate for a marriage in which several supernatural beings took part. This location, though, is not suitable for the observation of the astronomical phenomenon we have described. Oeta is visible from the summit of Pelion, but the direction of view between the two forms an angle of $c .48^{\circ}$ with respect to the east-west line. Since at this latitude the maximum deviation of the direction of sunset from the astronomical west is $c .3 \mathrm{I}^{\circ}$, it would be impossible to observe the evening star above Oeta. However, there was a lesser-known tradition offering a domesticated version of the story, with the wedding feast taking place at Peleus' palace. This variant features prominently in the François Vase (c. 565 B.C.), ${ }^{\mathrm{I}}$ whose main frieze depicts a procession of gods and goddesses heading towards the wedding of Peleus and Thetis. Peleus is represented in front of a building, welcoming the guests upon their arrival; the entrance is marked by two columns, and the half-open door allows the viewers to see Thetis

\footnotetext{
10 Shaw I997; cf. Arist., Pol. I332a.35-38.

11 At Catull. 64.38-42, when the Thessalian peasants interrupt their agricultural work to attend Peleus' marriage, the tools mentioned are those used for winter activities: loosening and weeding the soil (rastra), tillage (uomer, aratrum), pruning ( falx).

12 On the mythographic tradition about the marriage of Peleus and Thetis, see Bloch I897-I909: I833-9; Reitzenstein I900.

13 schol. (D) ad Hom., Il. I6.140= Cypr. fr. 4 West (West 2013: 69-75). Cf. among others Pind., Nem. 5.22; Eur., IA 704-705, I036-I048.

14 Firenze, Museo Archeologico Nazionale, inv. 4209. Torelli 2007; Shapiro et al. 2013.
} 
waiting inside. Admittedly, this alternative location is very rarely attested: the only surviving literary sources which accept it are Catullus 64 and Lucian, Dial. mar. $7 .{ }^{{ }^{5}}$ Nonetheless, the François Vase shows that some Greeks, at least, could imagine this episode taking place in a domestic setting already in the archaic period.

In sum: the association of Hesperus with Oeta refers to an astronomical observation made from the region which the Iliad identifies as Phthia. Given its recurrence in epithalamic contexts, it is likely that this motif was originally connected with the marriage of Peleus and Thetis, the most famous wedding of Greek mythology, which took place in that area. By mentioning Hesperus and Oeta, the Latin poets were probably alluding to a Greek model narrating this event - either a fictitious epithalamium celebrating that occasion, or a real epithalamium which used that myth as an exemplary comparison. This lost poem described the marriage (or at least the wedding banquet) as taking place not on Mount Pelion, as in the epic tradition, but at Peleus' palace. The preference for this version, which removed some of the most alienating aspects of the myth by relocating it to a domestic setting, may suggest a date in the Hellenistic period, when traditional characters were portrayed from less conventional points of view and depicted as more human, sometimes even 'bourgeois'. However, a more precise identification of the model remains speculative: the suggestion that the late Hellenistic poet Parthenius could be the inventor of the motif, though fascinating, is entirely unprovable. ${ }^{\mathrm{I} 6}$

In epithalamic poetry, the myth of Peleus and Thetis was a flexible and effective celebratory tool: the bride could be likened to the most beautiful of the Nereids, whom Zeus himself had desired, while the bridegroom could be depicted as an example of virtue and piety like Peleus, whom the gods judged worthy of a divine wife; moreover, the poet could express the hope that the marriage would produce offspring as glorious as the great Achilles. In the next sections I will examine how the association between Hesperus and Oeta was appropriated in Latin poetry, exploring the twofold reception of this motif: as an allusion to that famous mythological wedding and, in more general terms, as a marker of the epithalamic genre.

III THE ALLUSION AS A GENERIC MARKER IN CATULLUS 62

In extant Latin literature, this motif first appears in the astronomical observation which opens Catullus 62: ${ }^{\mathrm{I}}$

Vesper adest, iuuenes, consurgite: Vesper Olympo

exspectata diu uix tandem lumina tollit.

surgere iam tempus, iam pinguis linquere mensas, iam ueniet uirgo, iam dicetur hymenaeus.

Hymen o Hymenaee, Hymen ades o Hymenaee!

\footnotetext{
15 Pontani 2000: 270-I, followed by Fernandelli 20I 2: 55-8, I47-8, suggested that this alternative location may have been implied already in Hesiod's Catalogue of Women (Hes., Cat. fr. 2 I I Merkelbach-West). The Hesiodic fragment, however, does not narrate the wedding itself but rather Peleus' return to Phthia: we cannot rule out the possibility that the marriage was celebrated earlier at a different location.

16 Parthenius, who according to the Etymologicum genuinum used the word Oitoîos somewhere in his works (Suppl. Hell. 666 = Parth. fr. 53 Lightfoot), would be the ideal candidate as potential disseminator of the motif thanks to his links with the neotero $i$ and Vergil. However, contrary to what has often been assumed (notably by Reitzenstein I9I2: 3 n. I), there is no indication that Parthenius used this word in an epithalamium. Indeed, the plural Oitoior is found in his surviving prose work, the Erotika Pathemata, to identify the people living around the mountain (Parth., Amat. narr. 25.I). It must be kept in mind that Parthenius, due to his fondness for lesser-known characters and places, was often used as a repertory of geographical references: Oi $\alpha i$ ios may be just one of many geographical words taken from this convenient source.

17 The text is quoted from Mynors I958. All translations are mine.
} 
Cernitis, innuptae, iuuenes? consurgite contra;

nimirum Oetaeos ostendit Noctifer ignes.

sic certest; uiden ut perniciter exsiluere?

non temere exsiluere, canent quod uincere par est.

Hymen o Hymenaee, Hymen ades o Hymenaee!

Vesper is here, young men, rise up all together: now at last

Vesper raises through heaven ${ }^{18}$ his long-awaited lights.

Now it is time to rise up, to leave the rich tables, now the virgin will come, now the nuptial hymn will be sung.

O Hymen Hymenaeus, be with us, o Hymen Hymenaeus!

Maidens, do you see the young men? Rise up all together in response;

no doubt the Nightbringer is showing the Oetaean fires.

It is certainly so; don't you see how quickly they sprang up?

They did not spring up without a reason, they will sing a song which we should surpass.

O Hymen Hymenaeus, be with us, o Hymen Hymenaeus!

In epithalamic poetry, the appearance of the evening star signals the moment for the guests to leave the banquet and escort the bride to the bridegroom's house, singing the wedding hymn: this moment marks the bride's detachment from her parents and entrance into her new household, i.e. her passage from childhood to adulthood. ${ }^{\text {I9 }}$ The motif is attested already in Sappho fr. Io4a Voigt, blaming Hesperus for snatching away a girl from her

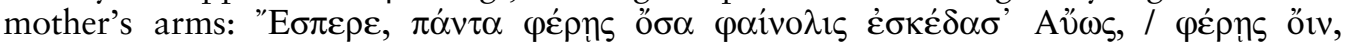

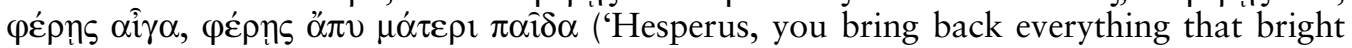
Dawn scattered: / you bring back the sheep, you bring back the goat, you carry away the child from her mother'). ${ }^{20}$

I begin with a detail which has been strikingly underestimated by most commentators on Catullus 62: while the young men witness the appearance of Hesperus, the girls do not. Only from the men's sudden rising do the girls infer that the star is visible. ${ }^{2 \mathrm{I}}$ Therefore, the young men and the girls must be banqueting in two different places with different observational capacity. The easiest explanation is that the youths are feasting outdoors, in a place from which they are able to see the sky (for instance a courtyard), while the girls are banqueting indoors: they cannot observe the sky but are able to see the young men standing up, probably through the open doors of the dining room. ${ }^{22}$ This separation of gender groups, typical of a Greek setting, also offers a solution to the long-debated issue of the supposed absence of the bride from the wedding banquet. ${ }^{23}$

\footnotetext{
18 Olympus is best understood here as a metonymy for 'heaven': Agnesini 2007: I66-7; cf. I7I-2 on the grammatical interpretation of Olympo as a prosecutive ablative or locative dative (in both cases it would be difficult to understand it as referring to the mountain).

19 Kidd I974; Wasdin 201 8: $55-80$.

20 Neri 2021: 774-6. On Sappho's epithalamia, see Ferrari 2007: II4-28.

21 This is confirmed by their use of nimirum (1. 7), strengthening the validity of their logical inference (cf. Verg., Aen. 3.558, 'nimirum hic illa Charybdis': Anchises does not see the monster but infers its presence from the loud noises it produces), as well as by 'sic certest' in 1. 8. See also Quinn I973: 275-7; on the uses of nimirum in general, cf. Schrickx 20II: I 85-209.

22 Friedrich I908: 28I (followed by Quinn I973: 275) suggested that both groups are feasting in a room with a wall open to the outside - the young men near the opening, the girls at the back. However, as Tränkle I98I: $25 \mathrm{I}$ pointed out, the girls see the young men but do not hear them: although the men explicitly say that the evening star has appeared, the girls seem to infer it only from their sudden rising. This suggests that the two choruses are located further apart, not within the same room.

23 Agnesini 2007: 66-75.
} 
If at the beginning of the poem the two choruses are located in two separate places, the young men's exclamation 'iam ueniet uirgo' (1. 4) does not imply that the bride is not taking part in the banquet, as has been generally assumed. It is easier to imagine that she has been feasting indoors with the girls; now that Hesperus has appeared, she and her companions will join the young men outside the house to start the wedding procession. The double-length final strophe of the introduction (ll. II-I 8), sung by the male chorus without a corresponding antistrophe by the girls, offers the best opportunity for this movement to take place: from 1. 20 onwards, the parallel structure of the hymn shows that the two choruses are singing in close proximity. ${ }^{24}$

The different observational capacity of the two choruses has some consequences on how the mention of Oeta is introduced. The girls' use of the adjective Oetaeus for the light of a star they do not actually see implies that they are aware of a connection existing between the star and the mountain. Of course, they may expect the star to be visible above Oeta simply because they know that, from their place of observation, this mountain is located on the western horizon. But the epithet 'Oetaean' conveys the idea of a pre-established association, deriving, in all likelihood, from the authority of an earlier tradition: this suggests that Oeta here is not primarily a geographical landmark, but above all the signal of an allusion. The ritual significance of the evening star activates the memory of the earlier poetic tradition, reminding the girls (and the readers) of the epithalamic connection between Hesperus and Oeta. This process is independent of the specific circumstances of the poem: there is no need for the star to be visible above Oeta during this particular wedding, nor for the wedding itself to take place near the mountain. The allusion allows for the light of Hesperus to be called 'Oetaean' simply because of the role played by this association in the epithalamic genre, without any need to retain the original topographical significance. Nor does the allusion necessarily conjure up the mythological exemplum of Peleus and Thetis, which is not really exploited in poem 62: the reference to Oeta is introduced to remind the readers not so much of that famous marriage as of the broader tradition of Greek epithalamic poetry.

Because of the mimetic structure of Catullus 62, its skilled literary technique is fictively attributed not to the poet himself, but to his characters. By referring to a tradition of associating Hesperus with Oeta, the girls advertise their own mastery of the epithalamic genre, its history and conventions. They are the ones who start the amoebean hymn by blaming Hesperus' cruelty (11. 20-22). While the young men had used the Latin word Vesper, the girls now address the star with the Greek vocative Hespere, reminding the readers not only of the Greek setting of the poem, but also, more specifically, of its antecedents: their complaint directly echoes Sappho fr. IO4a Voigt, which likewise opens

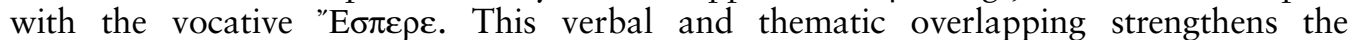
impression that the girls' performance is constructed as a homage to the Greek epithalamic tradition, and to Sappho in particular. ${ }^{25}$ Later the girls compare the bride losing her virginity to a flower which withers once plucked (1l. 39-47). Although this comparison has been traced back to several models, ${ }^{26}$ it is difficult to deny the

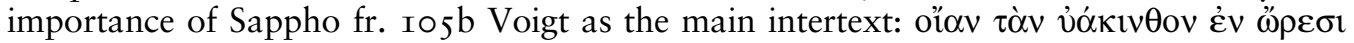

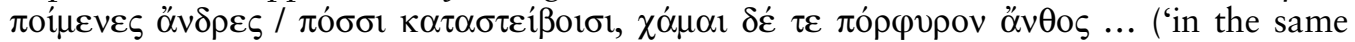
way, in the mountains, some shepherds tread down / the hyacinth with their feet, and the purple-coloured flower lies on the ground ...'). ${ }^{27}$ Admittedly, Sappho's hyacinth sprouts in the wild and gets trampled on by careless shepherds, whereas Catullus' flower is protected within an enclosed garden and gets plucked by delicate fingers, probably a

24 Contra Faraone 2020: 343, according to whom 'the bride ... never even arrives' and 'the performers remain standing near their seats'.

25 Agnesini 2007: 383-5; Faraone 2020: 340-4; Thomas 2021: 59-62.

26 Soph., Trach. I44-I 52; Eur., Hipp. 73-8 I. Cf. Agnesini 2007: 388-403.

27 Neri 202I: 779-80. 
girl's. These differences have been used to deny the relationship between the two images. However, a revealing hint comes from a parallel passage in Catullus 6I. Here too the exhortation to the bride to leave her father's house includes her comparison to a flower protected in an enclosed garden (Catull. 6r.87-89): 'talis in uario solet / diuitis domini hortulo / stare flos hyacinthinus' ('so beautiful a hyacinth flower / often stands upright in the multi-coloured / little garden of a rich gentleman'). In this passage, the explicit identification of the flower as a hyacinth unambiguously suggests a link to Sappho's fragment, showing at the same time how the Latin poet domesticated the image, transferring it from wild nature to a situation more familiar to his Roman readers. Without denying the possible influence of other models, the presence of the same motif in poem 6I confirms the importance of the Sapphic intertext for the simile of poem $62 .{ }^{28}$

While Catullus' girls draw their motifs from Sappho's epithalamia and are fully aware of their own role as heirs to that tradition, this does not mean that the young men do not know their Greek models too. Their literary expertise is revealed when they remark on the identity of the evening and morning stars (ll. 34-35): 'nocte latent fures, quos idem saepe reuertens, / Hespere, mutato comprendis nomine Eous'29 ('in the night the thieves hide, whom often you, Hesperus, catch, / coming back as the morning star, the same but with your name changed'). This certainly alludes to Callim., Hec. fr. 29I.3 Pfeiffer

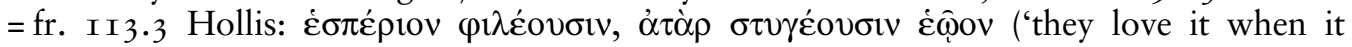
comes at evening but hate it when it comes at dawn'). This allusion, however, takes us out of the epithalamic tradition: not only does the Hecale belong to a different genre, but, as far as we know, the original context was not related to a wedding. ${ }^{3 \circ}$ Catullus' young men, though not inferior to their female competitors in their expertise in Greek literature, are less observant of generic boundaries. The girls' performance, by contrast, is structured as a sequence of well-known epithalamic commonplaces, designed to activate the internal memory of that genre; among these, pride of place is given to the association between Hesperus and Oeta, intended in my opinion not as a geographical indication, nor as a mythological reference, but primarily as a generic marker.

The performative structure of Catullus 62 contributes to setting the poem within an idealised Hellenic atmosphere. Catullus sketches a vague, undefined, timeless Greek world, whose inhabitants continually relate to their dignified ancestors by actively performing the literary technique of allusion. The Greek motifs, however, are domesticated to suit a different taste, as revealed by Sappho's hyacinth, taken away from its mountains and enclosed in the garden of an upper-class house. This cultural trend is also found in contemporary visual arts: the Greek girls reiterating epithalamic commonplaces in Catullus 62 perform a similar function to the statues alluding to acclaimed Classical models in the decoration of villas and gardens, or the reproductions of Greek paintings in the frescoes of Roman houses. Catullus partakes in the intellectual climate of his time in outlining a romanticised Greek world, which, while paying homage to its illustrious past, is crafted to match the expectations of contemporary Romans: an imagined theme park of literary and aesthetic sophistication, a foreign culture epitomised, domesticated, and ready to be appropriated.

This rarefied atmosphere of Hellenic idealisation shares some traits with the 'lost world of myth' described in poem $64,{ }^{3 \mathrm{I}}$ as both are constructed through the accumulation of Greek literary motifs. The approach to epithalamic commonplaces, however, is very different in the two poems. In poem 62, I argue, the allusion to Oeta is isolated from the mythological context to which it originally belonged; Catullus does not conjure up

28 On the use of the same image also in Catull. I I, cf. Thévenaz 20I9: I2I-3.

29 Eous is a compelling emendation by Schrader I776: I 5-I6 (pace Victor 2009).

30 Hollis 2009: 296-8.

31 Fitzgerald I995: I40-68. 
the exemplum of Peleus and Thetis, but rather uses this reference to activate the memory of epithalamic tradition in general. By contrast, in poem 64 , whose subject is precisely the marriage of Peleus and Thetis, Oeta is never mentioned. This absence, however, can be explained. As an epyllion, ${ }^{32}$ poem 64 shows a preference for different points of view and lesser-known variants of famous stories. One such variant is the relocation of Peleus' seat from the Homeric Phthia to the town of Pharsalus, which has the effect of removing Oeta from the local horizon; the mention of the mountain would therefore have been factually inappropriate in this context. On the other hand, if the association between Hesperus and Oeta was perceived as a marker of the epithalamic genre (and was used as such by Catullus), then it is also unsurprising that an epyllion should avoid it. There is of course an interplay with epithalamic poetry in Catullus 64, particularly in its final section with the nuptial hymn sung by the Parcae. But although Hesperus is mentioned towards the beginning of the hymn (1. 329), this mention does not take the usual form of the invocation; moreover, instead of simply reiterating the standard repertoire of praises and wishes to the newlyweds, the song quickly turns into a prophetic celebration of the offspring to be born from this marriage. ${ }^{3}$ Hence the mention of Oeta is not the only epithalamic commonplace which Catullus exploited in poem 62 and chose to avoid in poem 64. The reason, I believe, was the desire to distance the latter from some of the most distinctive epithalamic conventions, which would have been at the same time generically out of place and thematically over-predictable, and instead to prioritise the epic potential of the story.

\section{THE DISTORTION OF THE MOTIF IN VERGIL'S ECLOGUE 8}

In the first half of Vergil's Eclogue 8, the shepherd Damon gives voice to an unhappy lover's complaint about the haughty Nysa, who, having despised him (and every other suitor), is now being given in marriage to Mopsus. As the ironic reversal of an epithalamium, his song appropriates and subverts several commonplaces of the genre. This is explicit already in its first line (1. I7): 'Nascere, praeque diem ueniens age, Lucifer, almum' ('Rise, Lucifer, and, coming before it, drive forward the life-giving day' $\left.^{\prime}\right)^{34}$ - a transparent reversal of a characteristic epithalamic feature, the opening invocation to the evening star. While the conventional apostrophe to Hesperus anticipated the joy of the newlywed couple on their first night, this apostrophe to the morning star anticipates the protagonist's sorrow on the day in which his beloved will be carried away from him for good.

This process of subversion particularly informs the central section of the song, where several epithalamic motifs are distorted to sketch a tendentious and disturbing picture of the relationship between Nysa and Mopsus (11. 26-35):

\footnotetext{
Mopso Nysa datur: quid non speremus amantes?

iungentur iam grypes equis, aeuoque sequenti

cum canibus timidi uenient ad pocula dammae.

incipe Maenalios mecum, mea tibia, uersus.

Mopse, nouas incide faces: tibi ducitur uxor.

sparge, marite, nuces: tibi deserit Hesperos Oetan. incipe Maenalios mecum, mea tibia, uersus.
}

\footnotetext{
32 I use the word 'epyllion' for the sake of brevity, although I am aware that it is a modern scholarly category, accepting the definition given by Lyne I978: 172-3.

33 Fernandelli 20I 8; 2019.

34 Vergil's text is quoted from Ottaviano and Conte 2013.
} 
o digno coniuncta uiro: dum despicis omnis,

dumque tibi est odio mea fistula dumque capellae

hirsutumque supercilium promissaque barba,

nec curare deum credis mortalia quemquam.

Nysa is being given to Mopsus: what should we lovers not expect?

Now griffins will be joined with horses, and in the future

the fearful deer will come and drink together with the dogs.

Together with me, my flute, begin verses suited to Maenalus.

Mopsus, cut fresh torches: a wife is brought to you!

Scatter nuts, bridegroom: for you Hesperus moves away from Oeta!

Together with me, my flute, begin verses suited to Maenalus.

O you joined to a worthy husband, while you despise all men,

and while my pipe annoys you, as do my little goats,

my shaggy eyebrow and my long uncombed beard,

and you believe that none of the gods is concerned with mortal things!

In 11. 26-28, Nysa's marriage to Mopsus is depicted as totally unnatural: this union is said to be as abnormal as the cohabitation of animals belonging to different worlds (griffins and horses) or considered natural enemies (deer and hunting dogs). The sentence 'iungentur iam grypes equis' (1.27) is particularly sophisticated, because it plays on the double meaning of the verb iungo: 'to put animals in the yoke, harness to a vehicle or plough', but also 'to unite sexually'. ${ }^{35}$ If we accept the first meaning, we obtain a metaphor comparing the new household formed by Nysa and Mopsus to a vehicle pulled by two animals of different species, one able to fly, the other firmly based on the ground: such a vehicle will be impossible to drive, and the journey will end in a disaster. The situation does not get better with the second meaning: the mating between the two animals will either be infertile or produce monsters. This double scenario introduces two key themes of Damon's song: on the one hand, the newlyweds are depicted as belonging to completely different worlds, as alien to one another as the sky is to the earth; on the other hand, the auspicious character of epithalamic poetry is replaced by an obscure prediction of misfortunes, involving both the married life of the couple and their offspring.

Another epithalamic convention requires that the poet or the chorus address the bridegroom and the bride separately, celebrating their qualities, wishing them good fortune and fertility. At first glance Damon's song seems to comply with this, exploiting the standard repertoire of praises and good wishes; but, in reality, it gives voice to the jealous rival's hope for a less-than-happy ending for the newlyweds. The address to the bridegroom (11. 29-30) reiterates one of the most characteristic epithalamic commonplaces: the association between Hesperus and Oeta. Vergil, however, does not use this allusion simply as a generic marker, as Catullus did in poem 62. On the contrary, he fully exploits the mythological reference conjured up by the mention of Oeta, in order to endow this traditional motif with an entirely new meaning. The allusion resonates with the images deployed in the previous and following stanzas, contributing to the rejected lover's (mis)representation of the marriage between Nysa and Mopsus. By addressing the bridegroom with the words 'tibi deserit Hesperos Oetan', the protagonist implicitly compares him to Peleus, the hero during whose wedding the evening star shone above that mountain. This comparison traditionally praised the bridegroom as being as worthy as the king of Phthia, whose righteousness and piety earned him a divine wife. But if we read this allusion in the light of what has been said in the preceding stanza about the unnatural character of the union between

35 OLD, s.v.; cf. Serv. Dan. ad loc. 
Nysa and Mopsus, it acquires much darker tones. There, the bride and bridegroom had been compared to animals belonging to different species, whose union would be unmanageable and unfruitful. Now the comparison is transferred from the animal world to the mythological tradition: the spouses are as different from one another as a goddess is from a mortal. The apostrophe to the bride (1l. 32-35) brings this reasoning to its logical conclusion. Most commentators have noted the irony with which Mopsus is qualified as dignus uir, in sharp contrast to the indignus amor by which the protagonist has been fooled (1. I7). In reality, Nysa does not consider Mopsus worthy of her: she is being forced to marry a man whom she despises, since she thinks of herself as superior to every man ('dum despicis omnis'). The apostrophe to Nysa can be read in parallel with the preceding address to Mopsus. There, the association between Hesperus and Oeta had been used to compare the bridegroom to Peleus. Now the comparison is carried forward: as the gods judged Peleus worthy of a divine wife, so Nysa's parents have judged Mopsus 'a worthy husband' for their daughter. Thus Nysa is implicitly likened to Thetis, a goddess forced into a degrading marriage; as the gods gave Thetis to a mortal, Nysa too is being given to a man whom she considers unworthy of her.

This interpretation also sheds new light on the enigmatic 1. 35, 'nec curare deum credis mortalia quemquam' ('you believe that none of the gods is concerned with mortal things'). According to Servius ad loc., with these words the rejected lover represents Nysa's marriage as a punishment for having mistreated him: in addition to despising every man, in her arrogance she did not care about divine justice; therefore, the gods punished her haughtiness by allowing her marriage to an unworthy man. Those who accept this interpretation link this line to the very beginning of Damon's song: there, the rejected lover states that he will address his lamentation to the gods 'even if I gained nothing from having them as witnesses' (11. I9-20: 'quamquam nil testibus illis / profeci'). The ablative testibus illis echoes the language of juridical practice; as the Servius Danielis puts it (ad loc.): 'he says so as though an oath has been exchanged between him and Nysa'. This theory postulates that an exchange of vows had taken place between the two - a promise of love which the girl later broke, believing that the gods would not punish her for this. According to this interpretation, the protagonist accuses Nysa of perjury, and of being convinced that she will get away with it without incurring the wrath of the gods. ${ }^{36}$ However, nothing in the text suggests that Nysa took part in the protagonist's vows. The Servius Danielis itself presents the exchange of promises between the two, readily taken for granted by modern commentators, as a hypothetical comparison ('as though'); it may well be the case that what the gods witnessed was just the protagonist's own commitment and his prayer for the fulfilment of his love. More importantly, to support this reading the commentators are compelled to refer back to the alleged accusation of perjury fifteen lines earlier, without explaining the relevance of 1. 35 to its immediate context. I would instead interpret this sentence as yet another argument illustrating Nysa's haughtiness: by attributing to her the belief that 'none of the gods is concerned with mortal things', the protagonist implicitly accuses the girl of placing herself in the first group, i.e. among those disinterested gods. Nysa believes that she should not care about her husband, her rejected lover, or any other man, since she considers herself as distant from them as a deity is from mortals. This interpretation establishes a much closer connection between 1. 35 and its context. The protagonist begins by accusing Nysa of despising all men (1. 32), then focuses more closely on her contempt towards himself (1l. 33-34). If we read 1.35 as a rebuke for Nysa's haughtiness towards not just every man, but everything related to humans, then we can recognise in this stanza a sophisticated rhetorical structure combining a ring composition with a tricolon climax.

36 Clausen I994: 245-6; Cucchiarelli and Traina 20I2: 4I7. 
When interpreted this way, the apostrophe to the bride coherently develops the standard epithalamic comparison of the newlyweds with Peleus and Thetis, introduced by the reference to Oeta (and already alluded to, more obliquely, in 1l. 26-28 with the remark that the bride and bridegroom belong to different worlds). By focusing on Nysa's perspective, Vergil pushes the mythological comparison to its limit, exposing its inherent contradictions and exploring its darker side. If Nysa thinks that the distance between herself and her suitors is comparable to that between gods and mortals, then her marriage to Mopsus can indeed be presented as a punishment: like Thetis, Nysa considers herself degraded by being forced to marry someone whom she judges inferior. Mopsus, by contrast, can be seen as a new Peleus not for his heroic qualities, but because he has been awarded a bride much worthier than himself. This subversive approach is so powerful not least because it is supported by an ancient and well-established tradition. Already in the Iliad, Thetis complains to Hephaestus about her fate: she, alone among all goddesses, has been forced by Zeus to marry a mortal against her will, and will have to witness the physical decay of her husband and the untimely death of her only child (Hom., Il. I8.428-443) ${ }^{37}$. By retelling the story of Thetis' celebrated marriage from the bride's point of view, Vergil renders the tensions within it irreconcilable. The accusation brought against Nysa, of thinking of herself as a deity who should not mingle with mortals, takes the traditional epithalamic comparison to its breaking point, literally wishing the couple an unhappy marriage and an ill-fated offspring.

Vergil obtains this result through an unconventional approach to myth. In the Greco-Roman world, myth was a powerful instrument for self-identification. Gods and heroes were associated with specific qualities through the careful selection of certain aspects from the narrative contexts in which those characters were at play; the same mythological figures could be associated with different qualities depending on the episodes chosen and their relations to other characters. A typical example is offered by sarcophagi depicting Achilles and Penthesilea. ${ }^{38}$ The image of Achilles sustaining the dead Amazon's body was used as a metaphor for the mourning of a spouse over his deceased wife, visualising a set of values which partly celebrated the patrons' qualities (courage, beauty), and were partly more specific to the funerary realm (loss, grief, a love lasting beyond death). For the identification to work, however, the viewers needed to abstract these specific aspects from the general narrative, removing its most disturbing details - above all the fact that Penthesilea has been killed by her lover. The same approach can be found in literary narratives: the mention of an exemplary character or episode activated the association with a message or set of messages, requiring the audience to pinpoint, within a well-known story, those aspects which were being called up as terms of comparison. The exemplum of Peleus and Thetis in epithalamic poetry worked in the same way: as a rule, the poets and their audiences focused on its celebratory aspect, leaving aside the wedding's unhappy consequences in the epic tradition. Vergil, by contrast, subverts the conventional reading by requiring his audience to think about the whole story of the couple: from Zeus' decision to give Thetis in marriage to a mortal against her will, down to Thetis' attempt to spare her only child an untimely death in a war which originated during her wedding banquet.

The second narrative tool through which Vergil deconstructs the mythological exemplum is his focus on the female point of view. Epithalamic poetry was traditionally centred on male virtues and qualities, as is confirmed by the very choice of the wedding of Peleus and Thetis as exemplary comparison. This episode celebrates first and foremost the valour and piety of Peleus, whose divine wife can be seen as an exceptional

Slatkin I986.

38 Zanker and Ewald 2004: 42-6I. 
gift awarded to him by the gods, testifying to his privileged relationship with them. In the epithalamic genre, the female voice finds expression in the girls' ritualised performance of the bride's hesitation: but this tension is always resolved in her final acceptance of the marriage. By contrast, Damon's song focuses almost exclusively on the female perspective: while the bridegroom largely remains in the background, considerable attention is devoted to exploring the bride's feelings, especially her despisal of every man (including her husband). By approaching the motif from this point of view, Vergil exposes all the contradictions of the mythological comparison: the exaltation of the bridegroom is balanced by the degradation of the female element, as Peleus' exceptional honour finds its counterpart in the violence brought against his unwilling bride. Vergil requires his readers not only to broaden their perspective beyond the isolated mythological episode, taking into consideration the whole story, but also to think about the different points of view of its protagonists.

The novelty of this approach becomes particularly evident if we compare it with Catullus' retelling of the same myth in poem 64. There Catullus presents (in my opinion unironically $)^{39}$ the union between Peleus and Thetis as happy and faithful, pairing them with the only other instance of a marriage between a deity and a human, Dionysus and Ariadne, whose final bliss contrasts with the destiny of the disloyal Theseus. Contrary to mainstream epic tradition, in Catullus 64 Thetis is not forced to marry a mortal against her will; far from being the passive object of the gods' decision, she is given an active role in reciprocating Peleus' love (11. I9-2I) and is depicted as a loving and modest bride, very different from the offended goddess of the Iliad (ll. 328-336). ${ }^{40}$ The character of Thetis in Catullus 64 may therefore be interpreted as consciously anti-epic, a choice which befits the genre of epyllion. ${ }^{4 \mathrm{I}}$ Vergil, by contrast, builds on the established version of the myth: his depiction of Nysa's attitude is modelled on the Homeric portrayal of Thetis. One may even argue that his emphasis on the girl's disdain towards every man ('dum despicis omnis') is a direct rebuttal of Catullus' unconventional depiction of Thetis (Catull. 64.20: 'Thetis humanos non despexit hymenaeos'), stating Vergil's preference for the Homeric version over Catullus' rewriting. It is Vergil, in my opinion, who, by going back to the epic tradition and exploiting its potential for conflict, turned the traditional epithalamic comparison into an unsettling hint of future misfortunes, uttered by a rejected lover against the woman who despised him.

\section{COMBINING ECHOES: HESPERUS AND OETA AFTER VERGIL}

The association between Hesperus and Oeta is found again in the pseudo-Vergilian Ciris, an epyllion written probably in the first century A.D. by an author combining a general

\footnotetext{
39 I am aware that, in the last fifty years, studies of Catullus 64 have been dominated by a sceptical interpretation which sees the poem as an ironic construction, depicting the supposedly idyllic heroic age as faulted with disloyalty and savage violence. If we accept this reading, the reversal of the epithalamic exemplum which I attribute to Vergil should better be ascribed to Catullus. This interpretation, however, has been recently criticised by Fernandelli 20I2: xxiv-Xxxiv (cf. also Biondi 20I5; Fernandelli 20I5: 203-I3). I do not have the opportunity here to discuss this issue in more detail.

40 For the possibility that Catullus derived this version of the myth from Alc. fr. 42 Voigt, see Fernandelli 20I 2: $\mathrm{xv}-\mathrm{xvii}$; Bartol 2018 .

41 Of course, it is possible to interpret the idealisation of the union between Peleus and Thetis in Catullus 64 as ironic, based on how the epic tradition narrated the development of their story. This interpretation, however, presupposes Catullus' acceptance of the Homeric depiction of Thetis as the 'true' one, attributing the anti-epic portrayal of the goddess, in narratological terms, to a naïve narrator. This leads, in my opinion, to a paradox: the unreliable narrator would comply with the generic conventions of epyllion better than the author himself, whose irony would ultimately foster a restatement of traditional epic elements.
} 
neoteric style with a fondness for Vergilian echoes. ${ }^{42}$ Here, the reference to the planet Venus is varied to a great degree of sophistication (App. Verg., Ciris 349-354): ${ }^{43}$

Postera lux ubi laeta diem mortalibus almum
et gelida uenientem ignem quatiebat ab Oeta,
quem pauidae alternis fugitant optantque puellae
(Hesperium uitant, optant ardescere Eoum),
praeceptis paret uirgo nutricis et omnis
undique conquirit nubendi sedula causas.

When the Sun of the following day was happily pushing forward the daylight, which gives life to mortals, as well as the star coming from icy-cold Oeta, which timid girls alternately eschew and wish for (they seek to escape it when it comes at night, they wish for it to shine in the morning), the maid follows the nurse's instructions and diligently collects, from every side, all the reasons for marrying.

The passage provides a remarkably accurate description of the morning twilight, the moment shortly before dawn when the sky starts becoming brighter thanks to the sunlight scattering in the upper atmosphere. The precision of the chronological reference conveys the excitement of the young Scylla, so thrilled by the perspective of her love being fulfilled that she does not wait for the actual sunrise to start the preparations for her wedding. At the beginning of the passage, Venus is identified as 'the star coming from icy-cold Oeta'. This cannot be a factual astronomical indication, since Oeta is not visible from Scylla's city, Megara: the reference is best interpreted as alluding to the epithalamic commonplace associating the planet with this mountain. However, Oeta was traditionally linked to the evening star, while the Ciris passage refers to the morning star. As noted above, the identity of the two was common knowledge already in Classical Greece: here, the use of a periphrasis indicating Hesperus within a context pointing to Lucifer prepares the allusion of 1. 352: 'Hesperium uitant, optant ardescere

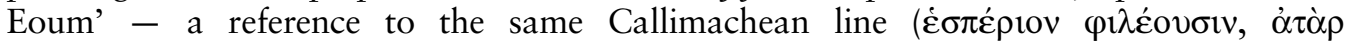

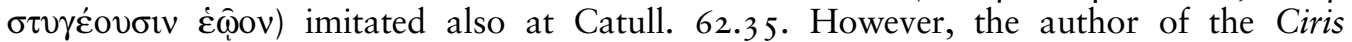
skilfully reverses the meaning of the intertext: whereas the protagonists of Callimachus' passage cherish the evening star and detest the morning star, ${ }^{44}$ the girls here do the opposite. Their fear of the evening star is a well-known epithalamic trope staging the bride's anxiety for the imminent loss of her virginity. This motif, too, had been exploited at Catull. 62.20-24, where the girls compare the bride's experience of the wedding night to the violence accompanying the plundering of a conquered city. In short, these lines accommodate a cluster of epithalamic allusions. Acute readers, who at this point have already received more than a hint at the unhappy outcome of Scylla's love, will sense the irony of these references, charged with darker tones not dissimilar to those of Eclogue 8. There, Vergil constructed his ominous foreshadowing by tightening the traditional comparison of the bridal pair with Peleus and Thetis and requiring his readers to look at that exemplary wedding from the bride's perspective. In the Ciris, by contrast, the mythological comparison is left in the background. The mention of Oeta certainly points towards it; but, in order for the allusion fully to deploy its

42 Bretzigheimer 2005; Peirano 20I2: I73-204; McGill 20I9: 69-7I. Lyne I978 dates the poem to the second/ third century A.D.; Gall I 999 and Kayachev 2016 argue for a date in the first century B.C.

43 The text is quoted from Lyne I978. On this passage, see Lyne I978: 250-3; Kayachev 2016: 92-3, I 28-3 I; Wasdin 20I 8: 7I-2.

44 Several identifications have been proposed for this group of people; Wasdin 20I 8: 67-8 convincingly suggests non-married lovers. 
potential, the readers would need to be aware of the deconstruction of the exemplum operated by Vergil and accept it as an accomplished fact. In other words: it is the influence of Eclogue 8 that gives the Ciris passage its gloomy character, channelling its epithalamic allusions towards the foreshadowing of Scylla's disaster. ${ }^{45}$

Vergil became a classic already in his lifetime, and every cultivated Roman knew his works from school. ${ }^{46}$ As regards the epithalamic commonplace whose history I have sketched in these pages, Vergil's influence proved particularly powerful: his reading, I suggest, became so normative that no poet after him felt comfortable in using this motif again with its original meaning. To be sure, the appearance of the evening star continued to be mentioned in epithalamic poetry as a reference to the wedding night and the loss of the bride's virginity, ${ }^{47}$ and Peleus and Thetis remained a standard mythological comparison for the bridal pair until the late antique period; ${ }^{4}$ but the connection of Hesperus to Oeta is never found again in epithalamic contexts. It is tempting to argue that the reason was the subversion of this commonplace in Vergil's Eclogue 8, where the association between Hesperus and Oeta had been turned into an ill omen for the newlyweds, and in the Ciris (also attributed to Vergil in antiquity), ${ }^{49}$ where the mention of 'the star coming from icy-cold Oeta' anticipates the tragic outcome of Scylla's love. When the link between Hesperus and Oeta is found in later poetry (in the pseudo-Vergilian Culex and in Statius), it always remains at safe distance from any epithalamic connection. The appearance of the evening star is used as a mere chronological indication, and its association with Oeta is called up simply as an erudite reference. ${ }^{50}$ This is not to say, of course, that in these authors the mention of Oeta is 'used at random', to borrow Fraenkel's words: its incorporation is a way to play with the readers' expectations and challenge their knowledge of Vergil, Catullus and their Greek antecedents. But, in the absence of any epithalamic connection, the memory of the genre is not activated, and no further associations are developed. Decontextualisation, in other words, was the only way in which it was still possible to use this allusion, deactivating the ominous implications attached to it by Vergil.

\section{CONCLUSION}

The Roman reception of the association between Hesperus and Oeta illustrates the remarkable variety of approaches by the Latin poets to the repertoire of literary commonplaces inherited from their predecessors. I have argued that, in the Greek antecedent which Fraenkel had already postulated, the mention of Oeta was used as a

\footnotetext{
45 That Eclogue 8 is the key intertext of this section of the Ciris is suggested by the author's choice to combine the two aspects of the planet Venus: by doing so, the poet establishes a connection with the double mention of the star in Damon's song (Lucifer in 1. I7, Hesperus in 1. 30), taking over the ominous implications attached to it by Vergil. The link with Eclogue 8 is further confirmed in the following lines by an even more explicit borrowing. When Scylla's nurse tries to bend her father's will through a magic rite, the poet devotes three lines (1l. 37I-373) to describing the repetition of some ritual gestures, overtly alluding to a similar three-line strophe from the second part of Eclogue 8 (11. 73-75): the borrowing is marked by verbatim quotations of two Vergilian hemistichs. Presenting his readers with a series of ill-fated epithalamic references followed by the description of a magic ritual, the poet of the Ciris alludes in a few lines to both sections of Eclogue 8. Cf. Munari I944: 284-98.

46 Tarrant 2019.

47 Claud. 9.I 5-I6, I4.I-4, Rapt. Pros. 2.36I-362.

48 Stat., Silv. I.2.21 5-217; Claud. 9, I0.174-I75; Sid. Apoll., Carm. IO, I4.26-30.

49 McGill 20I9: 73-5.

50 App. Verg., Culex 202-203: 'iam quatit et biiugis oriens Erebois equos nox / et piger aurata procedit Vesper ab Oeta' ('already the night, daughter of Erebus, rising above the horizon pushes forward her horses yoked in a pair, / and slow Vesper appears above gilded Oeta'); Stat., Silv. 5.4.8-9: 'totidem Oetaeae Paphiaeque reuisunt / lampades' ('an equal number of times the torches of Oeta and Paphos / see me again and again').
} 
reference to the marriage of Peleus and Thetis, the mythological archetype of epithalamic poetry. This exemplary story was used by the Roman poets as a multi-layered intertext, in two respects: first, as a way to conjure up earlier iterations of the same motif in both Greek and Latin; second, as a reservoir of mythological materials, different aspects of which could be highlighted on each occasion. Catullus in poem 62 (an epithalamium) separated these two layers by dissociating the reference to Oeta from the myth to which it originally belonged; he treated the allusion as a generic marker to activate the internal memory of the epithalamic tradition, with no apparent interest in the mythological exemplum as such. Vergil, by contrast, in Eclogue 8 (not an epithalamium) used the reference to Oeta precisely to exploit its epithalamic connections, turning his shepherd's song into a distorted version of a wedding hymn and highlighting the contradictions inherent in the traditional mythological comparison. To do so, he asked his readers to consider all the layers of the intertext at the same time, bearing in mind the whole story of Peleus and Thetis as found in different genres (especially the epic tradition), and not just the festive episode of their wedding. In this way, Vergil attached a series of unsettling implications to the old epithalamic association between Hesperus and Oeta, which soon became normative due to his immediate and pervasive influence. Later authors either exploited these ominous overtones (as in the Ciris) or used the allusion as a mere erudite reference, deactivating its epithalamic associations (as in the Culex and in Statius). However, thanks to the multi-layered nature of the mythological intertext, the negative resonances attached by Vergil to this particular motif did not extend to the exemplum of Peleus and Thetis as a whole, which continued to be used as a favoured mythological comparison in epithalamic contexts. Apparently its positive aspects were not overshadowed by Vergil's darker implications, which seem to have concentrated only on the association between Hesperus and Oeta. This motif, which Catullus could single out as the epitome of Greek epithalamic tradition, completely disappeared from this genre after Eclogue 8; it was sacrificed, one could argue, to preserve Peleus and Thetis as epithalamic paradigm. The erasure of this motif from the genre in which it had originally developed is an impressive tribute to Vergil's influence: many poets can vary, subvert or deconstruct a received commonplace, but few have the power to annihilate it.

\section{Università di Pisa}

fabio.guidetti@cfs.unipi.it

\section{BIBLIOGRAPHY}

Agnesini, A. 2007: Il carme 62 di Catullo. Edizione critica e commento, Quaderni di «Paideia» 5, Cesena.

Bartol, K. 20I8: 'Catullo, 64,I9-2I: una reminiscenza alcaica?', Paideia 73, 739-47.

Biondi, G. G. 20I 5: Review of Fernandelli 2012, Gnomon 87, 497-506.

Bloch, L. I897-I909: 'Peleus', in W. H. Roscher (ed.), Ausführliches Lexikon der griechischen und römischen Mythologie, vol. 3, Leipzig, I 827-45.

Bretzigheimer, G. 2005: 'Poeta memor ludensque oder The Making of Ciris', in N. Holzberg (ed.), Die Appendix Vergiliana. Pseudepigraphen im literarischen Kontext, Classica Monacensia 30 , Tübingen, I42-224.

Clausen, W. I994: A Commentary on Virgil, Eclogues, Oxford.

Coleman, R. (ed.) I 977: Vergil, Eclogues, Cambridge.

Cucchiarelli, A. and Traina, A. (eds) 20 2: Publio Virgilio Marone, Le Bucoliche, Lingue e letterature I4I, Rome.

Faraone, C. A. 2020: 'Stationary epithalamia in hexameters? The evidence from Sappho, Theocritus, and Catullus', American Journal of Philology I4I, 3 I 7-48.

Fernandelli, M. 20г2: Catullo e la rinascita dell'epos. Dal carme 64 all'Eneide, Spudasmata I42, Hildesheim, Zürich and New York. 
Fernandelli, M. 20 I5: Chartae laboriosae. Autore e lettore nei carmi maggiori di Catullo (c. 64 e 65), Quaderni di «Paideia» 20, Cesena.

Fernandelli, M. 2018: 'Puluinar diuae geniale. Sintesi culturali e ampliamento spirituale nel carme 64 di Catullo', in F. Fontana and M. Murgia (eds), Sacrum facere: Atti del V Seminario di Archeologia del Sacro. Sacra peregrina: la gestione della pluralità religiosa nel mondo antico (Trieste, I7-I9 novembre 20I6), Polymnia Io, Trieste, 37-53.

Fernandelli, M. 2019: 'Sulla genesi del canto delle Parche (Catull. 64,303-383)', Paideia 74, I33-52.

Ferrari, F. 2007: Una mitra per Kleis: Saffo e il suo pubblico, Biblioteca di «Materiali e discussioni per l'analisi dei testi classici» I9, Pisa.

Fitzgerald, W. I995: Catullan Provocations: Lyric Poetry and the Drama of Position, Classics and Contemporary Thought I, Berkeley, Los Angeles and London.

Fo, A. (ed.) 201 8: Gaio Valerio Catullo, Le poesie, Nuova Universale Einaudi. Nuova serie 20, Turin.

Fowler, D. 2019: 'The Virgil commentary of Servius' (revised by S. Casali and F. Stok), in Mac Góráin and Martindale 2019, 88-94.

Fraenkel, E. I955: '«Vesper adest» (Catullus LXII)', Journal of Roman Studies 45, I-8.

Friedrich, G. (ed.) I908: Catulli Veronensis Liber, Leipzig and Berlin.

Gall, D. I999: Zur Technik von Anspielung und Zitat in der römischen Dichtung: Vergil, Gallus und die Ciris, Zetemata roo, Munich.

Head, B. V. I884: A Catalogue of the Greek Coins in the British Museum. Central Greece (Locris, Phocis, Boeotia and Euboea), London.

Hollis, A. (ed.) 2009: Callimachus, Hecale, 2nd edn, Oxford.

Kayachev, B. 20I6: Allusion and Allegory: Studies in the Ciris, Beiträge zur Altertumskunde 346, Berlin and Boston.

Kidd, D. A. I974: 'Hesperus and Catullus LXII', Latomus 33, 22-33.

Lyne, R. O. A. M. 1978: Ciris: A Poem Attributed to Vergil, Cambridge Classical Texts and Commentaries 20, Cambridge.

Mac Góráin, F. and Martindale, C. (eds) 2019: The Cambridge Companion to Virgil, 2nd edn, Cambridge.

McGill, S. 2019: 'The Appendix Vergiliana', in Mac Góráin and Martindale 2019, 63-76.

Munari, F. I944: Studi sulla 'Ciris', Atti della Accademia d'Italia. Memorie della Classe di Scienze morali e storiche, Serie VII, 4.9, Rome.

Mynors, R. A. B. (ed.) I958: C. Valerii Catulli Carmina, Oxford.

Neri, C. 202 I: Saffo, Testimonianze e frammenti. Introduzione, testo critico, traduzione e commento, Texte und Kommentare 68, Berlin and Boston.

Ottaviano, S. and Conte, G. B. (eds) 2013: P. Vergilius Maro, Bucolica, ed. S. Ottaviano; Georgica, ed. G. B. Conte, Bibliotheca scriptorum Graecorum et Romanorum Teubneriana 20I I, Berlin and Boston.

Peirano, I. 20I2: The Rhetoric of the Roman Fake: Latin Pseudepigrapha in Context, Cambridge.

Pontani, F. 2000: 'Catullus 64 and the Hesiodic Catalogue: A suggestion', Philologus 144, 267-76.

Quinn, K. I973: Catullus, The Poems. Edited with Introduction, Revised Text and Commentary, 2nd edn, London and New York.

Rehm, A. I9I 2: 'Hesperos', in RE VIII.I, I $250-7$.

Reitzenstein, R. I900: 'Die Hochzeit des Peleus und der Thetis', Hermes 35, 73-105.

Reitzenstein, R. I9I2: Zur Sprache der lateinischen Erotik, Sitzungsberichte der Heidelberger Akademie der Wissenschaften. Philosophisch-historische Klasse I9I2/I 2, Heidelberg.

Schrader, J. I776: Liber emendationum, Leeuwarden.

Schrickx, J. 20II: Lateinische Modalpartikeln: Nempe, quippe, scilicet, videlicet und nimirum, Amsterdam Studies in Classical Philology I9, Leiden and Boston.

Shapiro, H. A., Iozzo, M., and Lezzi-Hafter, A. (eds) 2013: The François Vase: New Perspectives. Papers of the International Symposium (Villa Spelman, Florence, 23-24 May 2003), Kilchberg and Zürich.

Shaw, B. D. I997: 'Agrarian economy and the marriage cycle of Roman women', Journal of Roman Archaeology Io, 57-76.

Slatkin, L. M. I986: 'The wrath of Thetis', Transactions of the American Philological Association I 6 , I-24.

Tarrant, R. 20I9: 'Aspects of Virgil's reception in antiquity', in Mac Góráin and Martindale 20I9, 43-62. 
Thévenaz, O. 20I9: 'Sapphic echoes in Catullus I-I4', in T. S. Thorsen and S. Harrison (eds), Roman Receptions of Sappho, Oxford, I I9-36.

Thilo, G. (ed.) I 887: Servii grammatici Qui feruntur in Vergilii carmina commentarii, vol. 3.I: In Vergilii Bucolica et Georgica commentarii, Leipzig.

Thomas, R. F. 202I: 'Catullan intertextuality', in I. Du Quesnay and T. Woodman (eds), The Cambridge Companion to Catullus, Cambridge, 47-69.

Torelli, M. 2007: Le strategie di Kleitias. Composizione e programma figurativo del vaso François, Milan.

Tränkle, H. I98I: 'Catullprobleme', Museum Helveticum 38, $245-58$.

Victor, B. 2009: 'Remarques sur Catulle 62, 34-35 et Cinna, fr. 6', Revue des Études Latines 87, 2 I-4. Wasdin, K. 20I 8: Eros at Dusk: Ancient Wedding and Love Poetry, Oxford.

Weizsäcker, P. I884-I890: 'Hesperos', in W. H. Roscher (ed.), Ausführliches Lexikon der griechischen und römischen Mythologie, vol. I, Leipzig, 2603-5.

West, M. L. 2013: The Epic Cycle: A Commentary on the Lost Troy Epics, Oxford and New York.

Zanker, P. and Ewald, B. C. 2004: Mit Mythen leben: Die Bilderwelt der römischen Sarkophage, Munich. 